\title{
GAUDÍ, A NEW ARCHITECTURAL CONCEPT OF MAXIMUM STRUCTURAL EFFICIENCY: CATENARY VAULTS, COMPLEX RULED SURFACES, BRANCHED PILLARS AND AN ENDLESS INNOVATIVE STRATEGIES
}

\author{
CARLOS SALAS ${ }^{1}$, CÉSAR BEDOYA ${ }^{2}$, JOSÉ M. ADELL ${ }^{3}$ \\ ${ }^{1} \mathrm{PhD}$ from the Polytechnic University of Madrid - ETS Higher School of Architecture \\ Department of Architectural Construction and Technology (DCTA) \\ Member of the Innovative and Sustainable Construction (TISE) Research Group \\ E-mail: carlossalasm@gmail.com \\ ${ }^{2}$ Professor at the Polytechnic University of Madrid - ETS Higher School of Architecture \\ Department of Architectural Construction and Technology (DCTA) \\ Member of the Innovative and Sustainable Construction (TISE) Research Group \\ ${ }^{3}$ Professor at the Polytechnic University of Madrid - ETS Higher School of Architecture \\ Department of Architectural Construction and Technology (DCTA) \\ Head of the Innovative and Sustainable Construction (TISE) Research Group
}

Keywords: Antonio Gaudí, structural efficiency, mechanical optimization, catenary vaults, catenary arches, ruled surfaces

\begin{abstract}
For the first time in the history of architecture, Antonio Gaudi used structural elements based on complex ruled surfaces - beyond traditional conical or cylindrical surfaces -, catenary vaults or branched pillars, in order to increase the structural efficiency of his buildings. The catenary arch had been used only in the construction of bridges by a few engineers, starting in the 18th century. Arata Isozaki said that the "scale model and the structural analysis of the church at the Güell Colony are the most original in the history of architecture". Beyond his artistic and creative genius - which has now been widely studied and acknowledged - Gaudi was a revolutionary architect, whose experimental approaches to the design and calculation of structures implied a focus that was so far ahead of its time that later, hugely significant engineers and architects have coincided with the methods and systems used by Gaudi half a century earlier. Norman Foster said in reference to Gaudí: "his methods, a century later, are still revolutionary".
\end{abstract}

\section{INTRODUCTION}

Antonio Gaudí - the architect of seven buildings on the UNESCO World Heritage List has been acknowledged as one of the great authors of the formal renovation of architecture in the twentieth century [1]; his artistic talent, the innovation in his natural architectural style with surprising forms and colours - his technical and constructive innovation, and even the bioclimatic progress in his architecture have all been valued. Not enough work, however, has been done on the importance of his person, the great legacy of his work in many other fields, such as sustainability and biomimetics in architecture; we could make special mention of the 
mechanical optimization of structural designs and structural efficiency.

We could state that the "significant formal renovation brought about by Gaudís architecture in the early twentieth century was not just an aesthetic or stylistic renovation, but also functional and technological, planting its roots deeply in numerous social, economic and environmental causes, the forerunners of modern ecology and sustainability" [2]. Antonio Gaudí was not just a great architect and a great artist - as is generally acknowledged - he was much more in addition; he was a great engineer and a great scientist, comparable to the great geniuses of the Renaissance, such as Leonardo Da Vinci and Michelangelo. Just like the great humanists of the Renaissance, he did not just study architecture and art, but also cultivated many other fields of knowledge; he devoted his life to study and research.

As shown in the $\mathrm{PhD}$ thesis entitled Antonio Gaudí, precursor de la sostenibilidad en la arquitectura [3], Gaudí may be seen as one of the fundamental forerunners of sustainability in architecture - 100 years ago - and at the same time, of twenty-first century biomimetic architecture too [2]; nevertheless, some of his most outstanding achievements - in the field of sustainability and biomimetics in architecture - are related to structural design, the fruit of the tireless quest for mechanical optimization and structural efficiency.

Gaudí - by means of a profound scientific study of mechanical models in nature - came up with surprising and innovative structural designs. These designs implied the first significant progress - in the field of structural architectural design - after many centuries of the cyclical repetition of the same mechanical principles: the mechanical principles of Gothic, Renaissance, Baroque, Neo-Gothic Examples of this inn Sagrada Familia Church the sa Park
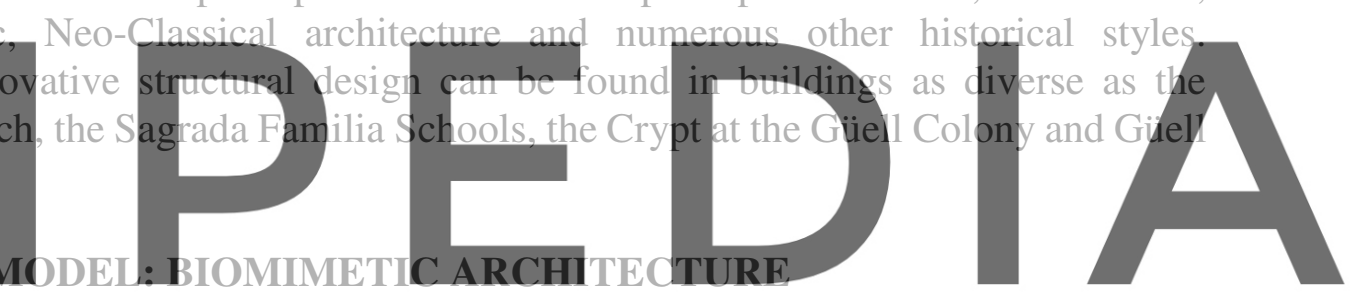

We could say that there are two creative forces: nature and mankind. Nature has its own

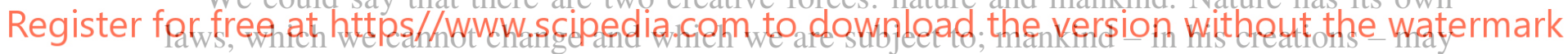

respect the laws of nature or go against them - fighting against the elements - whimsically or opportunisticaliy; this does not mean that mankind's respect for nature implies limiting his creative capacity, but rather simply bringing both creative forces together to avoid conflict between them [4]; creativity in Gaudí's architecture - and his respect for nature - is a good example of this.

Gaudí realized the importance of studying models in nature, not just aesthetically or artistically - as had been done throughout the history of architecture - but rather in a much more profound way; in a purely scientific way. Gustavo García Gabarró states that:

"Faced with architects' foolish passion for 'inventing' new forms that turn out to be a repetition or combination of previous ones (...) the great merit of Gaudí resides precisely in turning his gaze to nature, recognizing it as a generous teacher and maintaining a humble state of mind in its presence, not so much in order to invent anything but rather to discover it all" [4].

"This inspiration in nature is not approached as a romantic dream, removed from daily reality, but rather consists of working through the profound observation of the models nature has been rehearsing for millions of years, taking advantage of its experience, capable of reading wise lessons of welfare, economy and the reduction of costs, expressions so often repeated in 
today's world" [5].

En 1969, Ian McHarg published the book Design with nature [6], a pioneer in the concept of the "ecological project". In 2000, the Hannover Principles explicitly expressed the importance of nature as a model of sustainability and architectural efficiency: "Those who create and plan should practice humility in the face of nature. Treat nature as a model and mentor... [7]"'.

There is today a new science known as "biomimetics", in which - just as Gaudí said 100 years ago - nature is taken as a model, or source of inspiration, for the development of new technologies. Nature - in its 3.8 billion years of evolution - has developed extraordinarily efficient designs, the result of a lengthy process of adaptation to endless geographical, orographic, geological, biological, climatic and environmental variables; we could say that the complex equation of these variables has been solved by nature, giving rise to "smart design" structures. This kind of functional structure can be studied and mimicked - or more precisely, reinterpreted - in order to develop more efficient and more sustainable technologies.

Janine M. Benyus, the founder of the "Biomimicry Institute", says that "the first level of biomimicry is the mimicking of natural form, but you can reach a second level, which is when you mimic the natural process". Access to this second level is the great contribution of Gaudí's architecture, a century before the beginning of what we now know as "biomimetic architecture". The first level - i.e. the mimicry of natural forms on an aesthetic level - had already been used in architecture since ancient times.
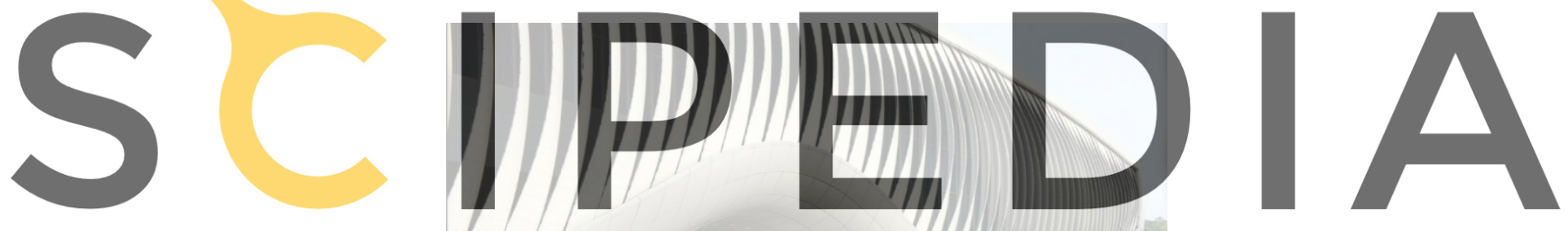

Register for free at https//www.scipedia.com to download the version without the watermark

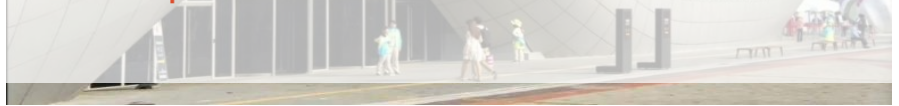

Figure 1: “One Ocean” Pavilion at EXPO 2012 (South Korea) Source: www.youtube.com/watchv=iCAGlu4vPog

By way of example, the thematic pavilion "One Ocean" (figure 1), at EXPO 2012 in Yeosu (South Korea) - designed by the Austrian company Soma - includes a folding system known as "Flectofin", inspired by the pollination mechanism in the Bird of Paradise flower, whose petals are capable of folding up to $90^{\circ}$; the system has no need for hinges, and operates on changes in the temperature. Ventilation and solar radiation can thereby be controlled.

\section{GAUDÍ'S GEOMETRY: BIOMIMICRY, SUSTAINABILITY AND STRUCTURAL EFFICIENCY}

We could say that geometry is architecture's own language, just as sound is for music, and language for literature [4]; this is why Gaudí said that: 


\begin{abstract}
"The architect should not talk vaguely (...) but rather specifically; his language is geometry" [8].

From the point of view of biomimicry, we could say that architectural design and the varied geometries of nature are the best model for efficiency and sustainability, as they are the result of a process of adaptation over millions of years (figure 2); the problem resides in its formal complexity and the difficulty in transferring it to the field of architectural design.
\end{abstract}
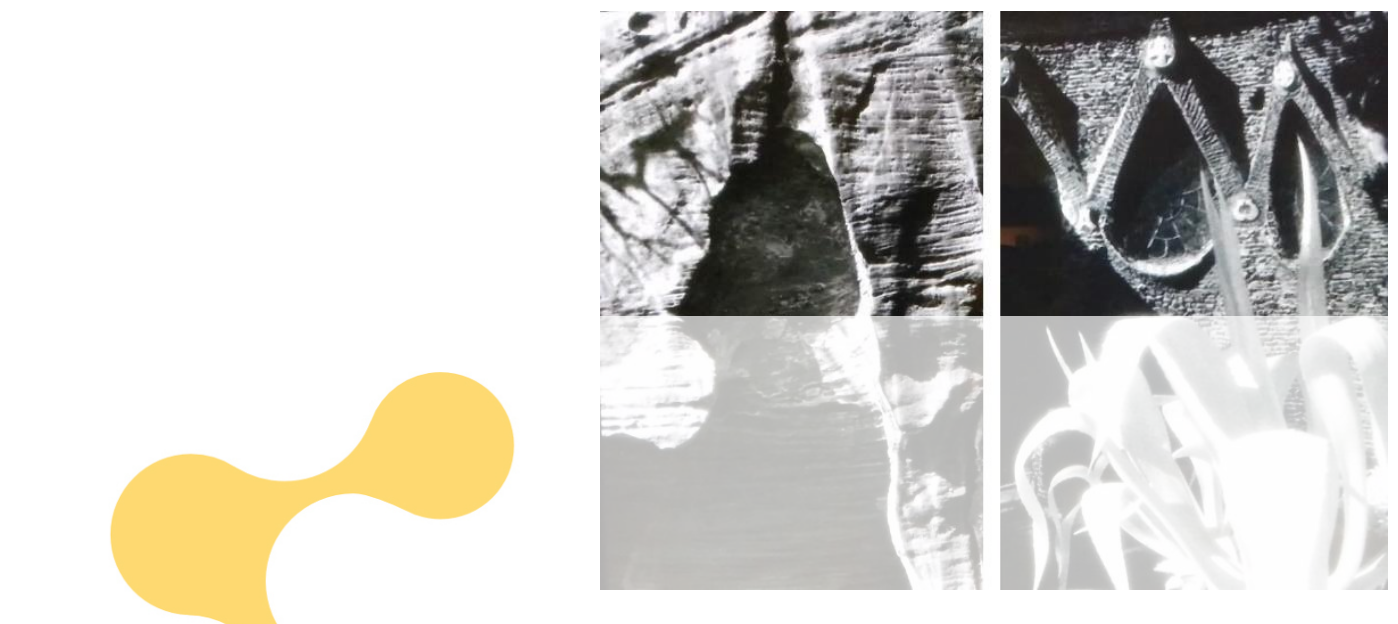

Figure 2: La Roca (Mont-Roig) and windows of the Crypt at the Guiell Colony
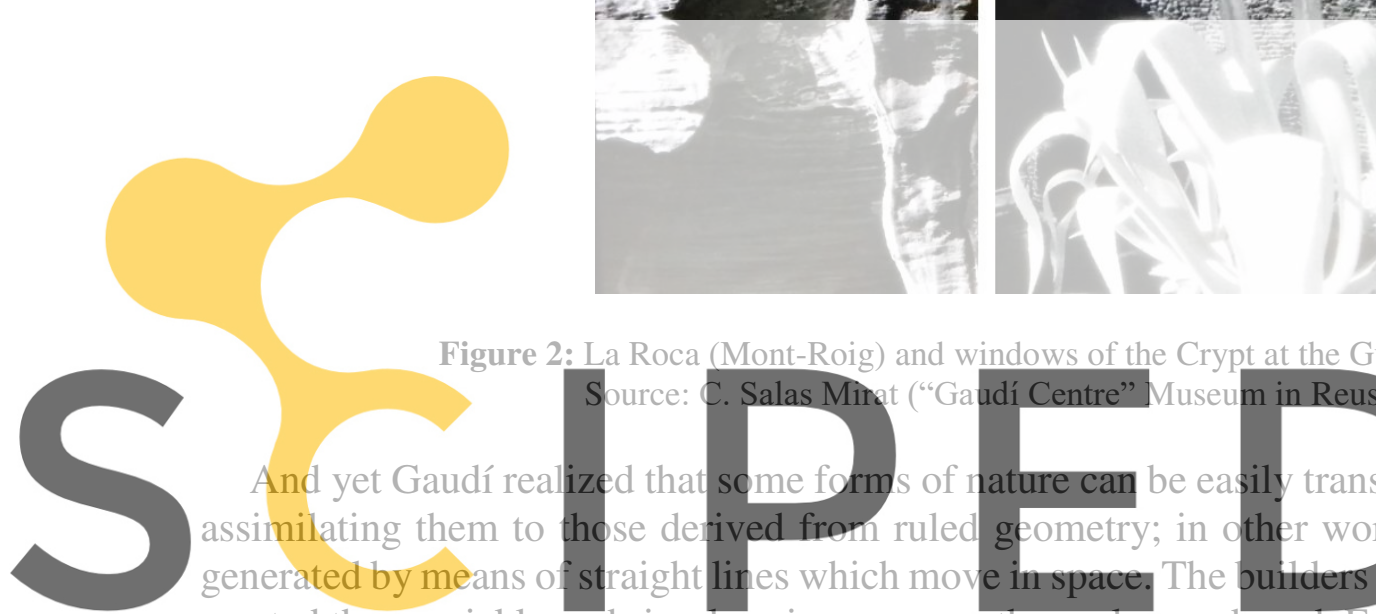

Figure 2: La Roca

And yet Gaudí realized that some forms of 1

assimilating them to th

generated by means of

erected them quickly and simply using no more th
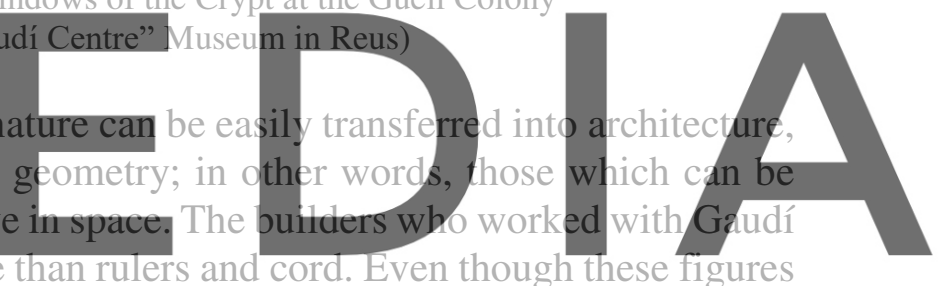
are not easy to depict graphically on plans, Gaudí also pvercame this problem, by working with

Register for free at https//wWw.scipedia.com to download the version without the watermark

For the first time in the history of architecture, Antonio Gaudí used structural elements based

on complex ruled surfaces - beyond traditional conical or cylindrical surfaces -, catenary vaults or branched pillars, in order to increase the structural efficiency of his buildings, saving huge amounts of material, improving the use of inner spaces [9], ventilation, illumination and exposure to sunlight, with the consequent savings in energy.

The vaults in the Sagrada Familia (figure 3) are formed by hyperboloids. These ruled surfaces are hollow in the middle - where the keystone was on old Gothic arches - and this means the vaults are lighter and their mechanical function is performed better, providing a great deal of natural light in the transepts. At the same time, at the intersection of the vaults - where the ribs were in the Gothic style - the hyperboloids open up small bays, achieving the effect of a starry sky. 


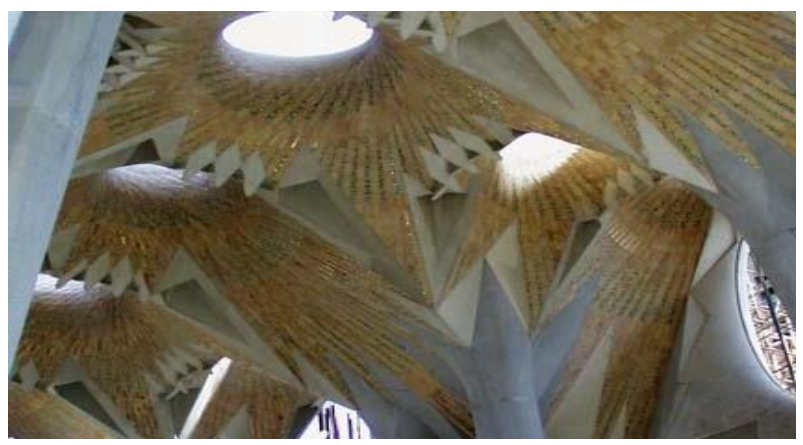

Figure 3: Vaults in the Sagrada Familia Source: esbocoseprojetos.wordpress.com/2017/04/02/exposicao-gaudi-barcelona-1900/

The Sagrada Familia Schools are built with just hollow brick tiles and wooden beams (figure 4). The technology employed is extremely simple. It consists of the traditional Catalonian vault, adapted to the shape of the conoid, as "this ruled surface could serve vertically to provide structural rigidity for the perimeter walls of the building, with a minimum use of materials and labour" [10]. Le Corbusier himself was impressed and publicly expressed his admiration for this little building when he visited it in 1928.
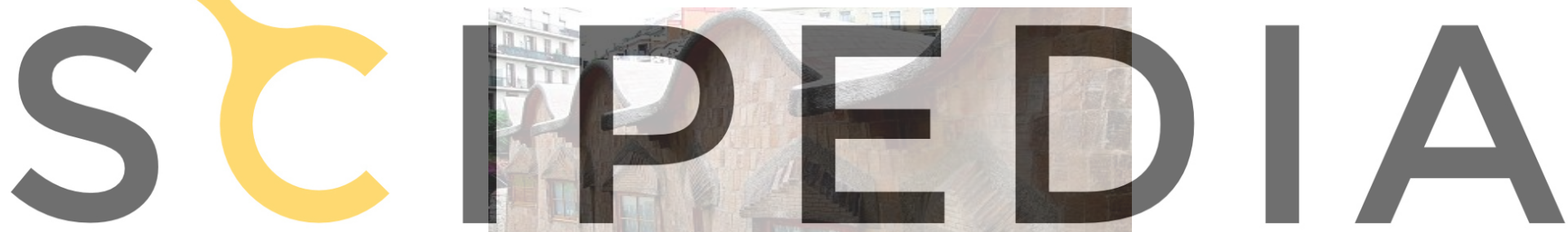

Register for free at https//www.scipedia.com to download the version without the watermark

Figure 4: Sagrada Familia Schools

Source: www.gypsynester.com/gaudi.htm

Gaudí said that the "true silhouette is born of the structure itself" [11]; and later on, Eduardo Torroja also said that "the best buildings are held up by their form and not by the hidden resistance of their material" [11].

\section{STRUCTURAL EFFICIENCY IN GAUDÍ}

Gaudí did not search for easy solutions, but on the contrary, he studied the advantages and disadvantages of each of his innovations in great detail; some of them are the fruit of many years of research, tests and trials.

Carlos Flores says that "the experimental approaches to design and the calculation of structures used by Gaudí were such an advanced solution to the problem for their time that later engineers and architects of great prestige have all inadvertently employed the methods and 
systems used by Gaudí half a century earlier" [12]; a good example of this is the double-curve ruled structure of the Olympic Park in Munich, built by Frei Otto in 1972 (figure 5).

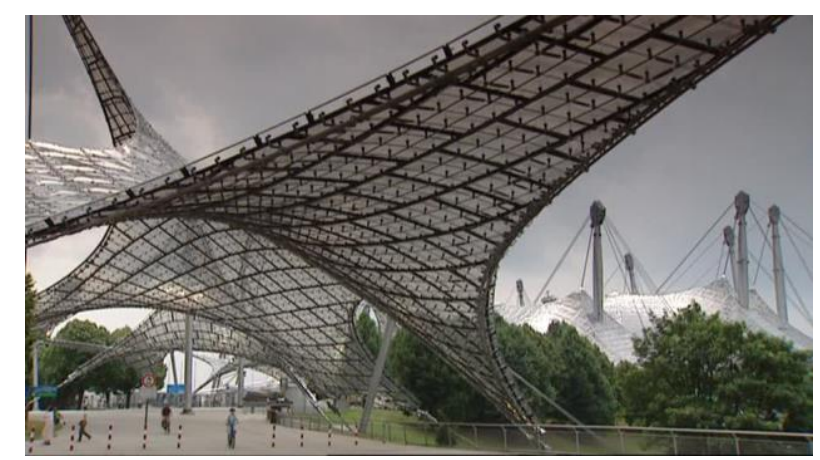

Figure 5: Olympic Park in Munich, Frei Otto

Source: footage.framepool.com/es/shot/665113940-estadio-olimpico-pilar-puntal-frei-otto

New information technology for structural calculation has shown how accurate Gaudís designs and calculations were. In 1986, the professors of structure at the Polytechnic University of Catalonia Juan Margarit and Carlos Buxadé calculated the structure of the Sagrada Familia Church, and saw that it coincided perfectly with Gaudí's previsions [13].

The calculation system developed by Gaudí in the stereostatic scale model of the Church at

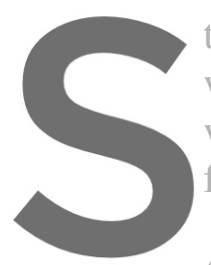
the Guiell Colony - in what was achieved by with what was known at the for the design of a build

4.1 Catenary arches, ruled surfaces and branching pillars
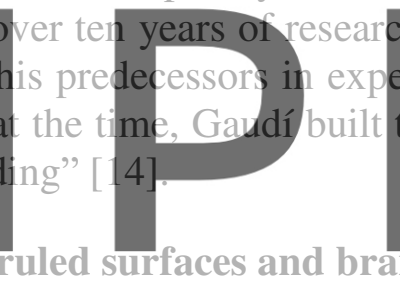

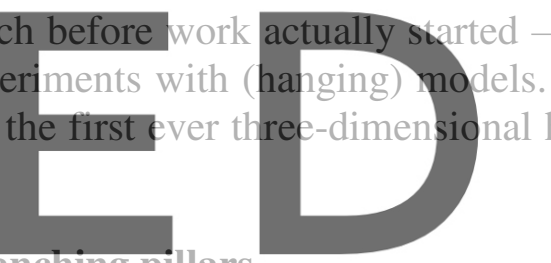

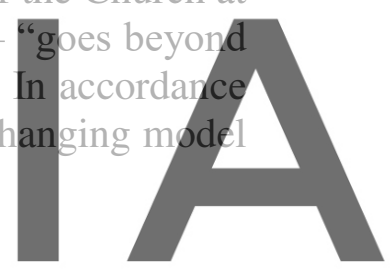

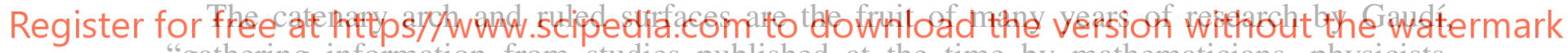
"gathering information from studies published at the time by mathematicians, physicists, biologists, architects and other scientists" [15]. The mechanical properties of the catenary have been known since 1691; the first mathematicians confused it with the parabola, until Dutchman Christiaan Huygens showed that they were in fact two different curves. In the history of architecture, however, this kind of arch was rarely used until it was rediscovered by Gaudí [16].

In ancient times, especially in the East, stable arches were intuitively built with the curvature of inverted catenaries. In Sudan, for example, catenary adobe vaults were built. However, western culture - from Greece and Rome - designed its arches and vaults based on curvatures derived from the circle; this type is easier to build, but less stable and efficient. During the Middle Ages and the Renaissance, catenary arches and vaults were forgotten in Europe, despite the poor functioning of the semi-circular arches. Later on, even the Gothic architects were unable to find the appropriate form to transmit the horizontal forces.

From the 17th century onwards, theoretical research on inverted catenary began. In 1675, Robert Hooke wrote that "as hangs the flexible line, so but inverted will stand the rigid arch" thus opening up the path for the investigation of catenary arches; in 1697, David Gregory showed that the arches are supported when they have a catenary inside; La Hire, from 1695 to 1712, studied in detail the friction between voussoirs and the stability of the arches; from 1730 
to 1732 , Complet and Danyzy carried out a number of mechanical experiments; in 1743, Giovanni Poleni, based on the investigation of the fissures in the Dome of Saint Peter, progressed in the study of the static model of the functioning of Gregory's catenary; in 1744, Euler carried out research on catenoid surfaces and consequently many other scientists mathematicians, physicists, architects, engineers, etc. - devoted themselves to the investigation of catenary arches and catenary vaults during the 17th, 18th and 19th centuries. However, all these studies on the inverted catenary were only put into practice by a few engineers, starting in the 18th century, for the construction of bridges. Therefore, they did not have repercussions in the field of architectural design - nor in the different architectural trends and styles of the 19th century - until the arrival of Antonio Gaudí.

At the end of the 19th century, Antonio Gaudí devoted himself to the in-depth study of all these sources during many years until he achieved - for the first time in the history of architecture - the development and systematic application of the catenary and other antifunicular arches in large buildings; he was the first to investigate and make use of them in his works. By way of example, as mentioned above, in the Crypt of the Colonia Guiell, ten years of studies with funicular models preceded the start of the works. In these years, Gaudí developed an ingenious and practical calculation system using funicular models based on strings and small bags of shot pellets (figure 6), of which he later took photographs from different angles. By turning the photographs upside-down, he obtained the layout of the catenary arches and the vaults.
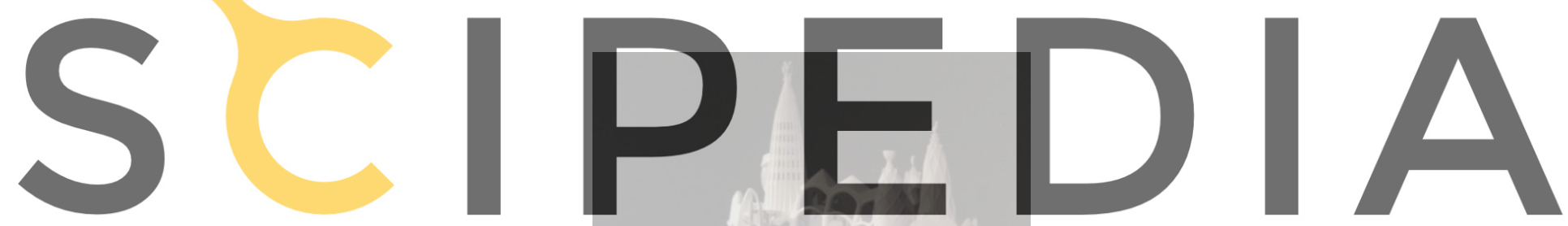

Register for free at https//www.scipedia.com to download the version without the watermark

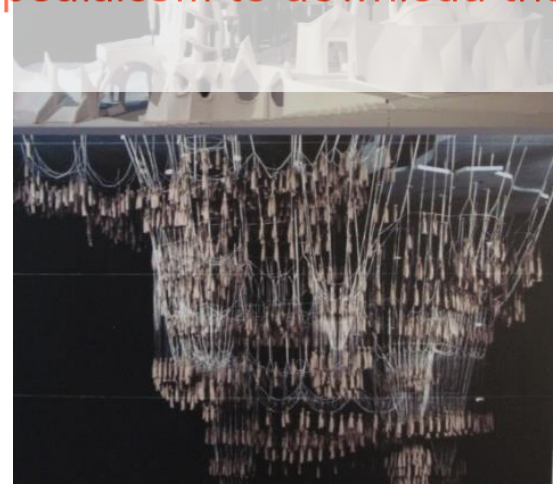

Figure 6: Funicular model of the Colonia Güell Church Source: C. Salas Mirat ("Diocesano" Museum in Barcelona)

However, the use of arches and catenary vaults are not Gaudís only great contribution to architecture in the field of structural design. In the Sagrada Familia, Gaudí's intention was to create architecture with new, more balanced and more resistant structures, to improve on the 
structures of European Gothic cathedrals. He therefore came up with pillars with a branching tree structure - based on a complex study of cord and weights, used in the crypt in the Güell Colony - which enabled him to determine the diameter and inclination of the pillars and the load transmitted onto the central core. He thus got the greater part of the structure to work under compression - instead of by flexion - and made the distribution of load more balanced, transferred onto the inner pillars and not just the perimeter elements. He was thus able to eliminate the huge Gothic flying and other buttresses, thereby saving material and space in the layout [3].

The branched tree structure of the pillars in the Sagrada Familia - like a self-supporting wood - eliminates the flying buttresses, which Gaudí called the "crutches of the Gothic style" [14]. Gaudí liked comparing the stability and resistance of Cologne Cathedral to those of the Sagrada Familia (figure 7), taking into account that with similar spans, the pillars cross-section of the latter is three times less, and in the buttresses four times less [17]:

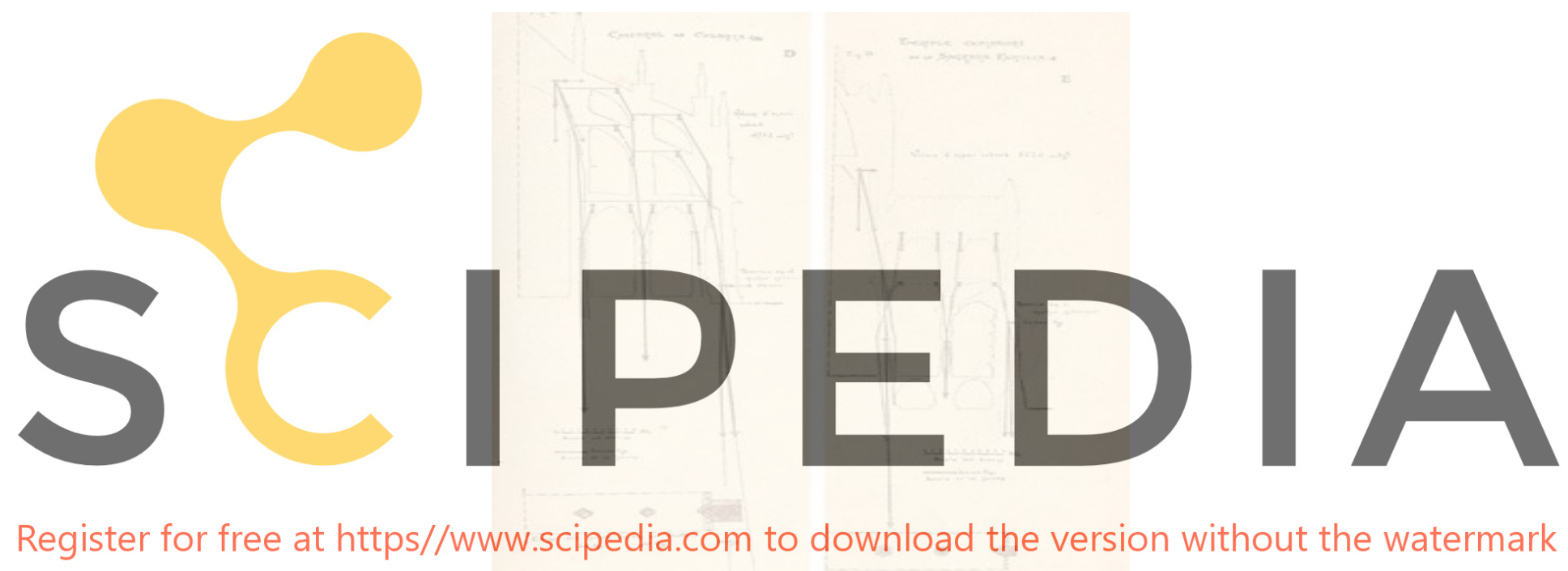

Figure 7: Pillars and buttresses in Cologne Cathedral and the Sagrada Familia Source: www.sagradafamilia.cat/sf-cast/docs_instit/estructura1.php

"When Gaudí took charge of the Sagrada Familia, which started out in the Gothic style - at the time this was almost compulsory for religious buildings - his main concern was how to diminish the inclined force, which would have meant building buttresses, flying buttresses and spires which act as mainstays and dead weights to verticalize the force. His spirit of synthesis could not accept the complex of centrifugal force which acts in Gothic churches and favours the disintegration of the elements, compensated by parasitical superstructures of dead weights and contrary thrust which tend to compensate the disintegrational force" [18].

Furthermore, in the Sagrada Familia Church the parabolic belfries with a circular horizontal cross-section, designed by Gaudí, reduce the wind force by over half - one of the main problems when building at height - in comparison to the continuous square horizontal cross-section belfries - designed by Francisco de Paula del Villar - in the original project. The openings in 
the belfries also contribute to this [17].

Gaudí thereby brings together three fundamental principles: mechanics, geometry and construction, in order to produce a logical architecture in which each element fulfils its function with the minimum effort. The "mechanical" fact is manifested "geometrically" and specified in the appropriate "constructive" element [18].

\subsection{Other structural innovations by Gaudí}

In the Casa Milá, Gaudí - ahead of his time - placed one of the first garages in Barcelona in the basement; in order to achieve a more open space, he designed an innovative metallic structure with radial beams - shaped like a bicycle wheel - which was later mimicked in the United States pavilion at the Universal Exhibition in 1958 (figure 8), where it was the object of great praise [19]. It is a radial structure with triangular metallic beams, joined in the middle to a metal ring and resting on metallic pillars on the outside [9].

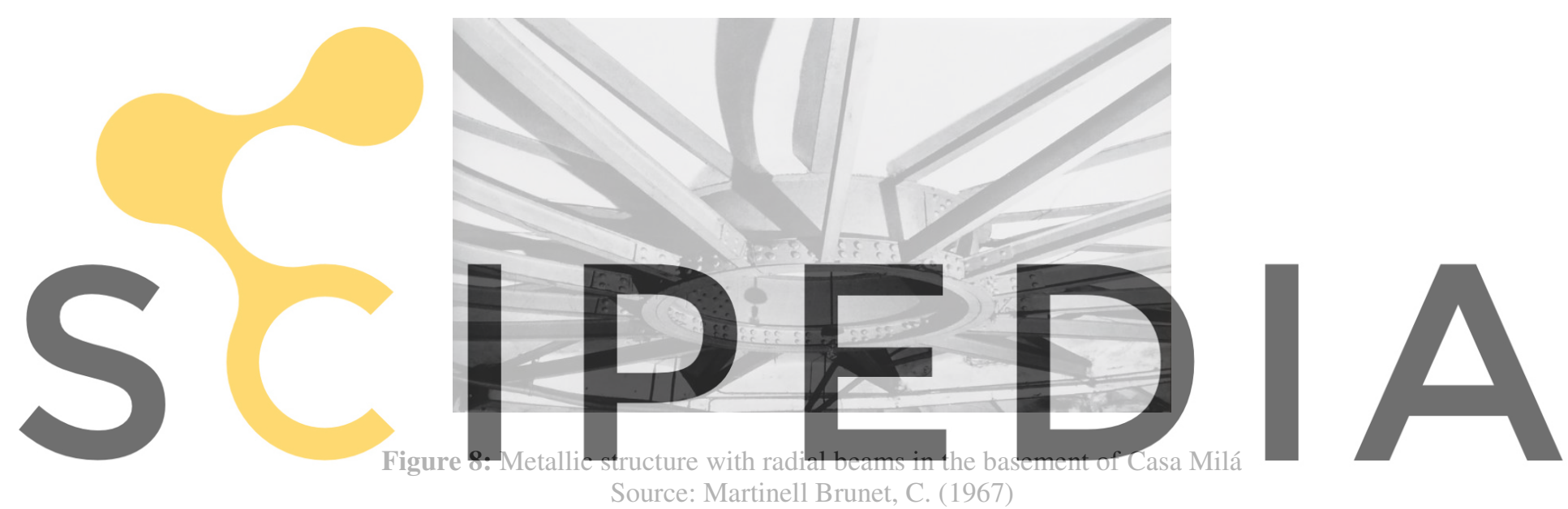

Register for free at https//www.scipedia.com to download the version without the watermark Still in Casa Milá, Gaudí designed an innovative metallic structure - lying on a base of mainstays and pillars - replacing the heavy load-bearing walls which buildings had at the time [20]. This structure enabled large spans and almost clear floors; i.e. the "Le Corbusian open floor, which Gaudí anticipated in this project" [21]. Furthermore, the elimination of the loadbearing walls meant considerable financial savings [18], and the possibility of opening up large spaces on the front for the ventilation and illumination of buildings, with the consequent savings in energy.

In the Güell Palace, the coffered ceiling in the visiting room is surprising thanks to its daring mechanics; its spatial structure boasts a greatly resistant efficacy, anticipating the future structures of reticular beams. Likewise, the ceiling in the dining room and the adjoining rooms is made up of reticular beams with Hispano-Muslim decoration [22].

In the Bellesguard Tower, we could say that Gaudí anticipates ribbed forging by an original brick design, whose solidity means that no joists were needed [23].

\section{CONCLUSIONS}

- The Catalonian architect Antonio Gaudí was not just a great architect and artist extremely ingenious and creative, as is generally acknowledged - but also a great 
scientist and a great engineer, who devoted many years of his life to researching the calculation of structures. He made such great progress in the concept of mechanics and the structural design of buildings that his contributions defined a before and after in the history of architecture.

- $\quad$ From a structural point of view, Antonio Gaudí was the author of a change which was many centuries in the coming; Gothic architecture was a significant step forward, but in the subsequent centuries - the Renaissance, Baroque, Neoclassicism, etc. - there had been no further significant progress in the field of structural design.

- Gaudí is one of the fundamental forerunners of sustainability and biomimicry in architecture; at the same time, he was the author of a new concept of organic architecture, of great mechanical perfection and innovative, never before imagined geometries: complex ruled surfaces, branching pillars, inclined pillars, catenary vaults and arches and endless geometries with the greatest possible structural efficiency.

One might think that Gaudí's architecture was of great value in its historical moment, but that today it is a difficult model to follow, however nothing could be further from the truth. As was mentioned at the beginning, some of the world's most prestigious architects of the 21st century, such as Norman Foster, have come to affirm that: "Gaudi's methods, one century on, continue to be revolutionary" [17]. In order to fathom this, one must understand that interpreting the message of Gaudí's architecture is not about imitating his forms, textures or colours - or even his innovative

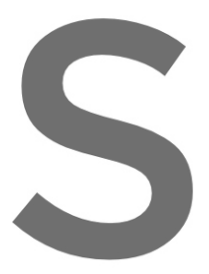
construction systems which he studied his
ecology, fundtionality
and the genius of his
search for authentic s
that have been describ
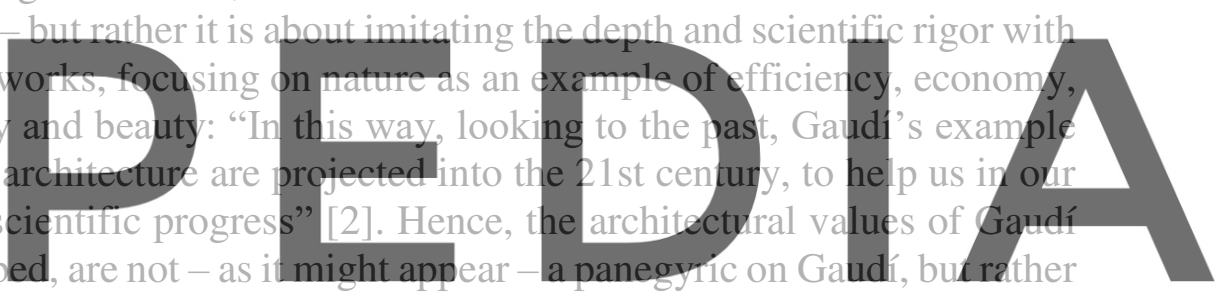

a rigorously scientific argument.

Register for free at https//www.scipedia.com to download the version without the watermark Acknowledgements. We are grateful for the collaboration by the TISE (Innovative and Sustainable Construction Techniques) Research Group and the Architectural Construction and Technology Department (DCTA) of the Higher School of Architecture at the Polytechnic University of Madrid (ETSAM - UPM).

Authors' contributions. The first author wrote the Paper, the second author reviewed the contents of sustainability in architecture and the third author reviewed the contents of Gaudi's construction systems. The authors declare that there is no conflict of interest.

\section{REFERENCES}

[1] González Moreno-Navarro A. Gaudí, constructor (la materialización de una arquitectura singular). Informes de la Construcción. (1990);42(408 julio-agosto).

[2] Salas Mirat, C., Bedoya Frutos, C. and Adell Argilés, J.M. Antonio Gaudí, precursor de la sostenibilidad y la biomimética en la arquitectura, con 100 años de antelación. ACE: Arquitectura, Ciudad y Entorno. (2018);13(37 junio). 
[3] Salas Mirat, C. Antonio Gaudí, precursor de la sostenibilidad en la arquitectura [tesis doctoral]. Universidad Politécnica de Madrid; (2018).

[4] Bassegoda Nonell, J. and García Gabarró, G. La cátedra de Antoni Gaudí: estudio analítico de su obra. Ediciones UPC, (1999).

[5] García Gabarró, G. Leyes de la naturaleza y composición arquitectónica: el ejemplo de Antonio Gaudí [tesis doctoral]. Universidad Politécnica de Cataluña; (1994).

[6] Mac Harg, I. Design with nature. American Museum of Natural History, (1969).

[7] McDonough, W. The Hannover principles: design for sustainability. William McDonough \& Partners, (1992).

[8] Puig Boada, I. El pensamiento de Gaudí. Dux, (2015).

[9] Vila Rodríguez, R. El uso del hierro en la Casa Milá de Barcelona. Informes de la Construcción. (1990);42(408 julio-agosto).

[10] Bonet Armengol, J. Las Escuelas de la Sagrada Familia. Escudo de Oro, (2002).

[11] Andrés, O. and Ortega, N. Extensión de la técnica funicular de Gaudí a la concepción y génesis de superficies estructurales. Informes de la Construcción. (1993);44(424 marzoabril).

[12] Flores López, C. Gaudí, Jujol y el modernismo catalán, Tomo I. Aguilar, (1982).

[13] Bassegoda Nonell, J. El gran Gaudí. Ausa, (1989).

[14] Tomlow, J. El modelo colgante de Gaudí y su reconstrucción. Nuevos conocimientos para el diseño de la Iglesia de la Colonia Güell. Informes de la Construcción. (1989);41(404 noviembre-diciembre).

[15] Cussó Anglés, J. Disfrutar de la naturaleza con Gaudí y la Sagrada Familia. Milenio, (2010).

[16] Bassegoda Nonell, J., Bassegoda Musté, B. and Lloveras Montserrat, J. Aproximación a Gaudí. Doce Calles, (1992).

[17] Bergós Massó, J. Gaudí, el hombre y la obra. Lunwerg, (1999).

[18] Martinell Brunet, C. Gaudí: su vida, su teoría, su obra. Colegio de Arquitectos de Cataluña y Baleares, (1967). 
[19] Giordano, C. and Palmisano, N. La última obra civil de Gaudí, La Pedrera, Casa Milá. Dos de Arte Ediciones, (2011).

[20] Adell-Argilés, J. Arquitectura sin fisuras. Munilla-Lería, (2000).

[21] Flores López, C. Sobre arquitecturas y arquitectos. Colegio Oficial de Arquitectos de Madrid, (1994).

[22] González Moreno-Navarro, A. and Lacuesta Contreras, R. Palacio Güell Gaudí, itinerario de visita. Diputación de Barcelona, (2013).

[23] Giordano, C. and Palmisano, N. Guía visual de la obra completa de Antoni Gaudí. Dos de Arte Ediciones, (2011). 